\title{
Taxonomic contributions to genus Gypsophila in Turkey and a new taxon from Erzurum: G. venusta subsp. staminea
}

\author{
Hasan ÖZÇELİK ${ }^{1}$, Fevzi ÖZGÖKÇE2*๑ \\ ${ }^{1}$ Süleyman Demirel University, Science \& Arts Faculty, Department of Biology, Isparta, Turkey \\ ${ }^{2}$ Yüzüncü Yll University, Science Faculty, Department of Molecular Biology and Genetics, Van, Turkey \\ *fevziozgokce@yyu.edu.tr, ${ }^{1}$ hasanozcelik@sdu.edu.tr
}

Received : 08.09.2020

Accepted : 13.12 .2020

Online : 09.01 .2021

\section{Türkiye'deki Gypsophila cinsine taksonomik katkılar ve Erzurum'dan yeni bir takson: G. venusta subsp. staminea}

\begin{abstract}
Gypsophila species in Flora of Turkey had been divided into 4 groups as A, B, C and D. Annuals are in group A. The current key for identification of annuals (A Group) is not able to identify species and subspecies. Moreover, there are new species records in this group. Some Gypsophila taxa such as G. bitlisensis, G. elegans and subspecies of G. heteropoda are confused to each other. In this study, annual Gypsophila taxa and confused subspecies were revised, up to date identification keys were prepared and G. venusta Fenzl subsp. staminea Özçelik and Özgökçe is described as a new taxon from Erzurum (Turkey). The list of Turkey's Gypsophila taxa was also updated. Though the existance of G. gracilescens and G. erikii seem to be doubtfull due to the unavailability of new samples from the determined localities, 63 Gypsophila species currently exist in Turkey. Some observations related to taxonomic and geographical characters of the taxa are provided.
\end{abstract}

Key words: Gypsophila venusta subsp. staminea, G. bitlisensis, G. elegans, current list.

Özet: Türkiye Florası'ndaki Gypsophila türleri A, B, C ve D olmak üzere 4 gruba ayrılmıștır. Tek yıllıklar A grubundadır. Tek yıllıkların (A Grubu) mevcut teşhis anahtarı türleri ve alt türleri ayırt edememektedir. Dahası, bu grupta yeni tür kayıtları vardır. Gypsophila bitlisensis, G. elegans türleri ve G. heteropoda'nın alt türleri gibi bazı Gypsophila taksonları birbiriyle karıştırılmaktadır. Bu çalışmada, tek yıllık Gypsophila taksonları ve karışık alt türler gözden geçirilmiş, güncel teşhis anahtarları hazırlanmıș ve G. venusta Fenzl subsp. staminea Özçelik ve Özgökçe Erzurum (Türkiye)'dan yeni bir takson olarak tanımlanmıştır. Türkiye'nin Gypsophila takson listesi de güncellenmiştir. Belirlendikleri lokalitelerden yeni örneklerin temin edilememesi nedeniyle G. gracilescens ve G. erikii'nin varlığı şüpheli olmasına karşın, halihazırda Türkiye'de 63 Gypsophila türü vardır. Taksonların taksonomik ve coğrafi karakterlerine ilişkin bazı gözlemler verilmiştir.

Anahtar Kelimeler: Gypsophila venusta subsp. staminea, G. bitlisensis, G. elegans, güncel liste.

Citation: Özçelik H, Özgökçe F (2020). Taxonomic contributions to genus Gypsophila in Turkey and a new taxon from Erzurum: $G$ venusta subsp. staminea. Anatolian Journal of Botany 5(1): 6-18.

\section{Introduction}

The genus Gypsophila L. was first described by Linnaeus (1753) and has more than 150 species (Anonymous, 2020a). Sixty three Gypsophila species (41 endemic) are currently known in Turkey (Barkoudah 1962; HuberMorath et al., 1967; Davis et al., 1988; Ataşlar, 2000; Ekim, 2012; Armağan, 2016). Huber-Morath's revision of Gypsophila L. in 'Flora of Turkey and the East Aegean Islands'(1967) provides a useful basis for the identification of the genus, but it has some serious shortcomings due to insufficiently studied specimens. Previously, Barkoudah (1962) made a revision of the genus and allied genera i.e. Phyrana Pax et Hoff., Ankyropetalum Fenzl, Bolanthus (Ser.) Rchb. which were separated from Gypsophila L. This revision is also important and served as a basis for the revision of Huber-Morath et al. (1967).

Gypsophila includes annuals, biennials and perennial herbaceous or semishrubs. Taxonomically it is related to Bolanthus (Ser.) Rchb., Ankyropetalum Fenzl and Acanthophyllum C.A. Mey. (Davis, 1967; Davis et al., 1988).

More than $50 \%$ of the total Gypsophila species currently exist in Turkey. Azerbaijan and Iran, respectively, follow Turkey in terms of Gypsophila species diversity (Schischkin, 1936; Rechinger, 1988). According to the Flora of Turkey (Davis, 1967; Davis et al,. 1988; Güner et al., 2000), 60 Gypsophila taxa belonging to 56 species had been reported. Thirty five of them are considered to be endemic. The genus is also among the genera to which maximum number of new species have been added after the publication of Flora of Turkey (Davis, 1967; Davis et al., 1988), and most of the Gypsophila samples are kept in GUL and VANF Herbarium. New Gypsophila taxa have been presented by subsequent studies, increasing the current species number of the genus in Turkey to 63 (Karagüzel and Altan, 1999; Ataşlar, 2000; Korkmaz and Özçelik, 2011a; Budak, 2012; Koç, 2013; Armağan, 2016; Armağan et al., 2017; Anonymous, 2020a).

Since new specimens of Gypsophila gracilescens Schischk. and G. erikii Yild. could not be found from the specified localities, the existance of these two species seem to be doubtfull. Though four species, G. pilosa Hudson, $G$. perfoliata L., G. sphaerocephala Fenzl ex Tchihat., $G$. viscosa Murr., of the genus are quite common, the others are rare or endemics.

Gypsophila is an economically important genus and the members having economic importance are named as "Çöven" by public, and seven species, G. bicolor (Freyn. \& Sint.) Grossh. (Van çöveni, Tarla çöveni), Gypsophila arrostii Guss. subsp. nebulosa (Boiss. \& Heldr.) Greuter \& Burdet (Beyşehir çöveni, Konya çöveni, Helvacı çöveni, Şekerci çöveni), G. paniculata L. (Bahar yıldızı), G. eriocalyx Boiss. (Çorum çöveni, Yozgat çöveni), $G$. 
bitlisensis Barkoudah (Bitlis çöveni), G. perfoliata L. (Niğde çöveni), G. elegans M. Bieb. (Bebek nefesi), are of economic impotance. Some members are used to make "Tahini Halvah", "Foam Halvah", "Turkish Delight", "Herbal Cheese" and "Çöven Bread". Some are used for the production of detergents, fire extinguisher, liquor and soap. Gypsophila arrostii var. nebulosa is used for commercial saponin production. Gypsophila elegans and G. paniculata are produced for floristry purposes (Korkmaz and Özçelik, 2011b). Beside the use of Gypsophila species for some health purposes such as diuretic, expectorant, acne remover, they are also used to polish gold at jewellery sector (Özçelik and Yıldırım, 2011).

Though its economic importace, Gypsophila is not known sufficiently in Turkish Flora. Thirty five of the 63 taxa were presented from East Anatolian region. Beside being endemic or rare, most of them are known only from type localities or from very few localities (Table 1). It is also the third largest genus in family Caryophyllaceae after Silene L. (c. 125 species) and Dianthus L. (c. 70 species) in Turkey.

Many studies (Özçelik and Özgökçe, 1995; 1999; Korkmaz and Özçelik, 2011a) have been carried out about the Gypsophila members of Turkey, and some new species and, new square records and new materials were presented from different regions. Although it is among the most complex genera of Turkish Flora taxonomically, a detailed revisional study related to Gypsophila hasn't been conducted.

The study aims to to clarify the problems in the taxonomy Gypsophila in Turkey and reveal information about the genus we have obtained during our work in different regions of Turkey.

\section{Materials and Method}

Research materials were collected from different regions of Turkey between 1988 and 2018, from February to September, both in the flowering and fruiting periods. Specimens were collected from as many different parts of the existing distribution area of the genus as possible to be able to study the variation patterns. The study area included East Anatolian vilayets, such as Van, Bitlis, Muş, Ağrı, Iğdır, Siirt, Şırnak, Bingöl, Erzurum and Hakkari provinces. Type specimens and the collections of herbaria ANK, ATA, E, EGE, FUH, GAZI, GUL, HUB, ISTF, KNYA and VANF were also examined. A range of characteristics that were considered to be taxonomically important in the genus was investigated.

Almost 150 collections from 75 localities were identified by using the second and supplementary volumes of Flora of Turkey and the East Aegean Islands (Davis, 1967; Davis et al., 1988). Twenty five of them belong to G. bitlisensis and G. elegans. The details about the collection sites of these plants; their direction, distance, biometric measurements, distribution patterns additional characters which were not given in previous revisions were also investigated. The differences from other publications were also noted (Table 1). Recent publications (Barrera and Arenas, 1999; Güner, 2012; Armağan, 2016; Armağan et al., 2017; Anonymous, 2020b) were taken into account in the spelling of the taxa authorities. Except for Table 2 and descriptions of taxa in results section, the authorities of the taxa were not given. Given authors are based on Huber-Morath et al. (1967), Rechinger (1988), Güner et al. (2000) and Güner (2012) with new publications (Budak, 2012; Hamzaoğlu, 2012; Yıldırımlı, 2012; Koç, 2013; Armağan, 2016; Armağan et al., 2017; Anonymous, 2020c).

All species of the genus were investigated by grouping them in four. Annual Gypsophila taxa (Group A) and perennials (Group B, C and D).

New identification keys and descriptions were prepared for subspecies and varieties of $G$. heteropoda, G. venusta, $G$. bitlisensis and G. elegans. All hesitant populations between $G$. elegans and $G$. bitlisensis were examined, after their species and populations were distinguished. A revised diagnostic key was prepared for annual members of the genus. A revision was made on Davis' (1967) key. Diagnostic features such as calyx shape, inflorescence and number of flowers, capsule shape and length, number of main stems in the plant, habitus of the plant, body length, leaf shape, size and indumentum, the shape and size of the brackets and the ratio to the calyx, pedicel length, thickness and indumentum, number of ovules in the ovary, indumentum in the calyx, shape, length, and structure of edges of the teeth, type and thickness of the underground organs, were used respectively while preparing the identification keys for Turkish Gypsophila members.

Abbreviations in the text and for table 2 are as follows:

*: Only known from type locality, rare; Mt: Mountain, el: Element, Euro-Sib.: Euro-Siberian, Medit.: Mediterranean, $\mathrm{Hb}$ : Herbarium/Herbaria; \pm : more or less; N: North, S: South; E: East, W: West; Prov: Province (vilayet in Turkish).

Collectors and researchers in the text: Altan: Yasin Altan, Behçet: Lütfi Behçet, Tatlı: Âdem Tatlı, MK: Mustafa Korkmaz, Özgökçe: Fevzi Özgökçe, A.Özçelik: Adnan Özçelik, Özçelik: Hasan Özçelik, A.Ç.: Ali Çelik, Muca: Belkıs Muca Yiğit; K.Aydınşakir: Köksal Aydınşakir.

\section{Results}

\subsection{Taxonomic contributions to some members of Gypsophila in Turkey}

3.1.1. Gypsophila venusta Fenzl subsp. staminea Özçelik and Özgökçe, subsp. nov.

Differt a subsp. venusta floribus minoribus; stamina in serie 2 disposita; flamenta $0.8-1.2 \mathrm{~mm}$ vel $2-3.2 \mathrm{~mm}$ longa, antherae 0.1-0.2 mm longae, in calyce inclusa, petala breve $5-6(-9) \mathrm{mm}$.

Type: B8 Prov. Erzurum: Aşkale-Erzincan highway, about $40 \mathrm{~km}$. from Aşkale, steppe, 2200 m, 23 vii 1993, Özçelik 6225 (HOLO in Hb. GUL and ISO in Hb. VANF).

Description: Plant 70-85 cm tall, strong, clearly swollen at nodes, whitish stemmed. Leaves lanceolate, acute to acuminate, 3-5 subveined, 10-60 x 1-10 mm, thin; papillose at margin; Inflorescence large, dense, many flowered paniculate-dichasial. Pedicels capillary, up to $25 \mathrm{~mm}$. Calyx 3-3.5 (-4) mm; petals 5-6(-9) mm; petals milk white, 2-2.5 x longer than calyx; widened cuneate and emarginate -retuse to truncate at the top. Calyx teeth about half of the tube with large scarious intervals. It has two different stamen groups (5 longer +5 shorter) which are never visible. Filament length of the short stamens $0.8-1.2 \mathrm{~mm}$, the others 2-2.5 (-3.2) mm; anthers 0.1-0.2 mm and style 3$3.5(-4) \mathrm{mm}$. long, visible. 
Notes: Features related to stamens and petal length bewildered us and provide the most important diagnostic characters. This new subspecies is based on differences in flower size, calyx and petal lengths, ratio of petals to calyx; stamen disposition, filament and anther sizes. At the same time, the region where it spreads, habitat and altitude are very different.

The two subspecies may be distinguished as below:

1. Stamens included in calyx, arranged in two groups as short and long; petals 5-6 (-9) mm, calyx 3-3.5 (-4) mm subsp. staminea

1. Stamens visible, apparently longer than calyx, similar one to other; petals 8-12 mm, calyx 3-5 mm ... subsp. venusta

Subsp. staminea is only known from the locus classicus. This taxon is apparently endemic (may probably occur in some areas of Ir.-Tur. region in Turkey) and is geographically isolated from subsp. venusta. According to the key in Turkish Flora (Davis, 1967), general characters of the type specimen resemble to G. venusta. But only petal length different to $G$. silenoides Rupr. We therefore propose to treat it as subspecies of G. venusta. Flower structure is somewhat anomalous, it has both short and long stamens. Thus, it differs from all other Turkish Gypsophila's and cannot be identified by the key given in Flora of Turkey (Fig. 1,2). The anatomical, ecological and palynological features of the species have been studied by us in comparison with other species. In addition, revision of the species and other ones in the Hagenia section were revised and a identification key was prepared (Fidan and Özgökçe, 2016).

Examination and comparison of Gypsophila venusta Fenzl. subsp. staminea Özçelik \& Özgökçe, subsp. nov. showed that it is not only merely an aberrant form of G. venusta with a smaller calyx and petals, but also features related to stamens and petal length bewildered us and provide the most important diagnostic characters. This new subspecies is based on differences in flower size, calyx and petal lengths, ratio of petals to calyx; stamen disposition, filament and anther sizes. At the same time, the region where it spreads, habitat and altitude are very different.

Subsp. venusta Fenzl subsp. venusta is known as "Konya Çöveni in Turkish". There are halva producers in Konya. They mix roots of G. arrostii Guss., G. perfoliata and $G$. venusta subsp. venusta uand also use for halva production (Koyuncu et al., 2008). G. venusta subsp. staminea is an endemic taxon with local distribution in Eastern Anatolia. There is no information about the use of subsp. staminea Özçelik and Özgökçe (Özçelik and Özgökçe, 1995).

Specimens examined: A.Özçelik \& K.Aydınşakir Ç.G.G. 140(GUL 13/24/46-1); A.Özçelik \& K. Aydınşakir, Ç.G.G. 93(GUL 13/24/46-2); A.Özçelik \& K.Aydınşakir Ç.G.G. 20(GUL 13/24/46-3); Özçelik \& A.Ç. 13 (GUL 13/24/465-13); Özçelik \& A.Ç.13(GUL 13/24/46/14-21); A.Özçelik \& K.Aydınşakir ÇGG 28(GUL 13/24/46-22); A.Özçelik \& K.Aydınşakir 11(GUL 13/24/46-23); A.Özçelik \& K.Aydınşakir 22(GUL 13/24/46-24); A.Özçelik \& K.Aydınşakir 88(13/24/46-25); Özçelik 12776 (GUL 13/24/46-26).

\subsubsection{Gypsophila elegans M. Bieb.}

A8 Prov. Bayburt: Kop Mountains, steppe, about 2300 m, 23 vii 1993, Özçelik 6229. Erzurum: Erzurum to İspir, between Rizekent and Çıkrıklı villages, steppe, on sandy places, $2100 \mathrm{~m}, 22$ vii 1976, Tatli 4914. Erzurum to Tortum; 6 km N of Karagöbek, 2200 m, 27 vii 1973, EGE 13595.
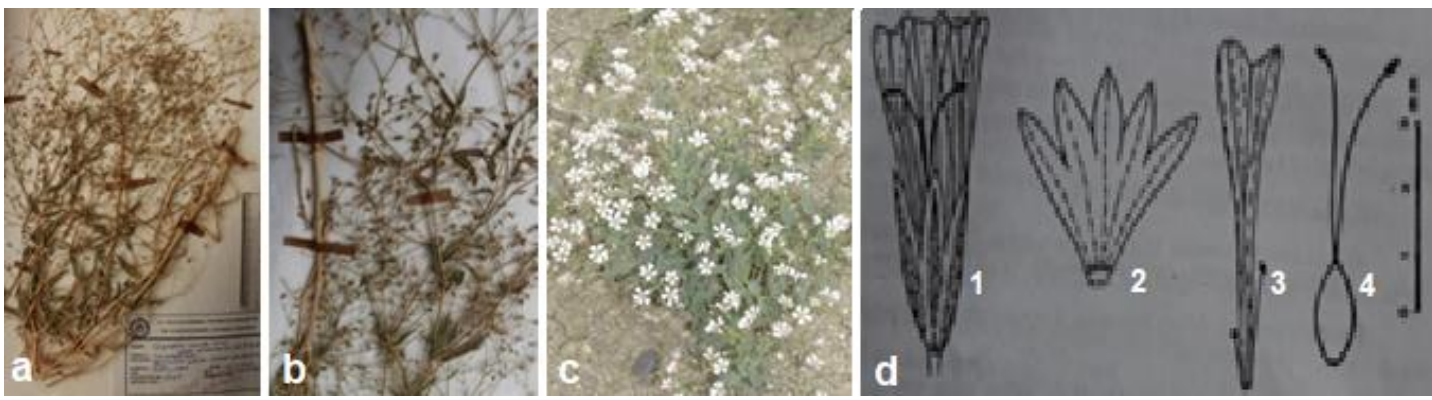

Figure 1. Gypsophila venusta subsp. staminea Özçelik and Özgökçe (a-c: habit; d1: flower; d2: dissected calyx; d3:petal and stamens d4: gynoecium) Özçelik 6225 (HOLO in Hb. GUL
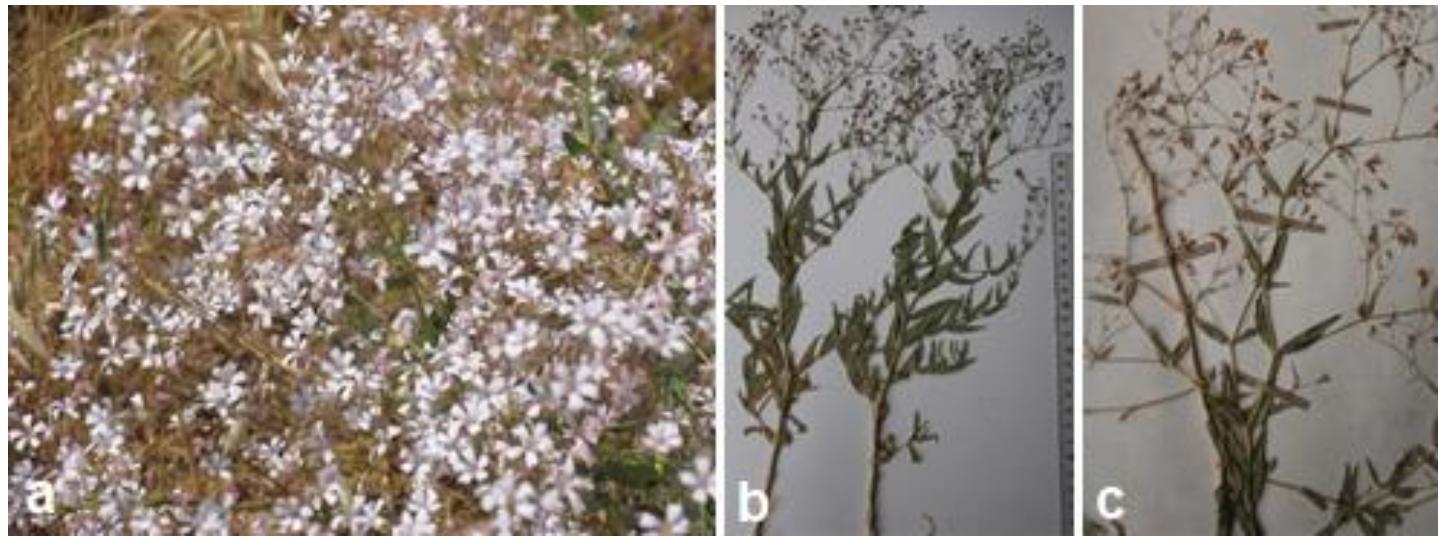

Figure 2. Gypsophila venusta subsp. venusta (a-c: habit) 
A9 Prov. Erzurum: Şenkaya, Gülveren village, Acisu locality, steppe, 2500 m, 26 ix 1984, FUH (Frrat Univ.) Altan 3903.

B9 Prov. Bitlis: Adilcevaz, Aydınlar village, $2200 \mathrm{~m}$, alpinic steppe; Adilcevaz (Bitlis)-Erciş (Van) road, 40-45 km, meadow, 21.05.1995, Özgökçe 2240(13/24/35-09); Özgökçe 2242 (GUL 13/24/35-10); Özgökçe 2243 (GUL 13/24/35-11); Özgökçe 2246 (GUL13/24/35-12); Özgökçe 2247(GUL 13/24/35-13); Özgökçe 2248 (GUL 13/24/3514); Özgökçe 2249(GUL 13/24/35-15); Özgökçe 2250 (GUL 13/24/35-16); Özgökçe 2252 (GUL 13/24/35-17); Özgökçe 2253 (GUL 13/24/35-18): Özgökçe 2272 (GUL 13/24/35-19); Özgökçe 2273 (GUL 13/24/35-20); Özgökçe 2274 (GUL 13/24/35-21); Özgökçe 2276 (GUL 13/24/3522); Özgökçe 2278, 2279 (GUL 13/24/35-23); Özgökçe 2280, 2281 (GUL 13/24/35-24); Özgökçe 4148 (GUL 13/24/35-25); Özgökçe 4158 (GUL 13/24/35-26); Özgökçe 2257, 2272, 2276, 2278, 2279, 2280, 2281, 2282(GUL 13/24/35-27).

Notes: Specimens vouchered as Özgökçe 2255, 2256 (GUL 13/24/35-28) are taxonomically problematic. Specimen with the voucher number MK. G. 51 is bottom branched and like biennial. MK. G. 83 seem like perennial.

B9 Prov. Van: Bahçesaray, Kavuşşahap Mountains, around Çatbayır village, field sides, 7 vii 1988, Özçelik 2245. Gürpınar, slopes of Başet Mountain, steppe, 2200 m, 4 vii 1993, Altan \& Özçelik 5288. Güzeldere Pass, 2200 m, 21 vi 1986, EGE 33213. Bitlis: Süphan Mountain, around Aydınlar village (Adilcevaz), steppe, 2200 m, 9 vi 1987, Behçet 255; Özgökçe 2240 (in VANF); ATA 620. The distribution area, in Turkey, is Eastern Anatolian region. Therefore, Tatlı 4914: Özçelik 2245, ATA 620, K. Aydınşakir Ç.G.G. 150 (GUL 13/24/35-2).

Notes: Specimens numbered as Tatlı 4914 (GUL 13/24/35/03-05) are hybrids with G. bitlisensis.

Specimen examined: A. Özçelik \& K. Aydınşakir Ç.G.G. 121 (GUL 13/24/35-1); A. Özçelik \& K. Aydınşakir Ç.G.G. 150 (GUL 13/24/35-2); Tatl1 4914-a (GUL 13/24/35/0305); Özçelik 2245 (GUL 13/24/35-06); A. Özçelik Ç.G.G. 94 (GUL 13/24/35-08); Özgökçe 2240, 2242, 2243, 2246, 2247, 2248, 2249, 2250, 2252, 2253, 2255, 2256, 2257, 2272, 2273, 2274 2276, 2278, 2279, 2280, 2281, 2282; 2249 4148, 4158, (GUL 13/24/35-10-28); MK. G.3, 5, 51, 200, 203, 296, 302, 330, 334, 339, 342, 352, 336, 397; ATA 620.

Notes: The distribution areas of the species mainly fall in Eastern Anatolian region and also spread in Eastern Black Sea region close to this region. Also, in Lakes region etc. Steppe, meadow and arid meadows are important habitats for it. Özgökçe 4158: Inflorescence lax, bract and bracteoles similar in shape, linear and pink. Rare and interesting specimen. Özgökçe 4148: Inflorescence congested, flowers small, bract and bracteoles similar to leaves in colour not pink, scarious (Figure 3).

Gypsophila elegans and $G$. bitlisensis are widely distributed in xerophytic and partially mesophotic habitats in the region. Our field observations indicated that identification of this group have many difficulties. Descriptions of these species have been given using few specimens. They are distinguished in the key as follows:
1. Inflorescence loosely dichasium; petals $2-5 \mathrm{x}$ longer than calyx; calyx 3-5 mm, main stem dominant, seeds bulging and tubers pronounced.......................................... elegans

1. Inflorescence densely dichasium, petals c. 1.5-2 x longer than calyx, calyx 2-3 mm, main stem many, seeds long and flat tuberred bitlisensis

According to the above key, many specimens of G. elegans deviate in qualitative and quantitative characters as well as general appearance, branching, stem number belonging to the same root, petal length and the ratio of petals to calyx. Our results show that even in the same population one can find plants with linear-oblong to linear bract shapes, flowers can be a few or many in number, arranged in dense or loose dichasiums and branched from base or in upper half.

\subsubsection{Gypsophila bitlisensis Barkoudah}

A8 Prov. Erzurum: Tortum, above salt pans, roadsides, 2160 m, 5 vii 1975, Tatlı 2101.

B9 Prov. Bitlis: Süphan Mountain between AhlatAdilcevaz cities, steppe, 2200-2800 m, 28 vii 1988, Özçelik 1711; Behçet 1215; Tatvan, Nemrut Mountain, steppe, 1700-2400 m, Aug. 1991, Özçelik 2620; W and N slopes of Yumurtatepe locality, 2250-2350 m, alpinic sandy steppe. 5 vii 1972, Tatl1 717. Por stream, near the centrum; ca. 1500 m, 23 vi 1983, Hb. FUH 7547 (Firat Univ., Elazığ).

Three types of G. bitlisensis occur in the mountains of East Anatolian region. The identification key of these types is prepared as follows:

1. Inflorescence dense and many flowered, only branched from base

2. Number of main stem many and stems short Group suphanis

2. Number of main stem one or a few and stems long ...... Group nemrutis

1. Inflorescence lax or little flowered, branched from base, near base or upper parts ............................... Group sarkis

Group.suphanis Özçelik and Özgökçe: Only grow on Suphan Mountain of Bitlis. Naming is new.

Group.nemrutis Özçelik and Özgökçe: Only grow on Nemrut Mountain of Bitlis. Naming is new.

Group.sarkis Özçelik and Özgökçe: 1-main stemmed, stems long or short (found in several localities of Van, Ağr1, Erzurum). Naming is new.

Specimen examined: Özgökçe 1971(GUL 13/24/37-1-2); Özçelik 5173(GUL 13/24/37-3); Özgökçe 1711 (GUL 13/24/37-04-05); Tatl 717(GUL 13/24/37-06); Tatl 2101(GUL 13/24/37-07); A.Özçelik 80 (GUL 13/24/3708); A.Özçelik 74(GUL 13/24/37-09); Özçelik 2264(GUL 13/24/37/10-11); Özçelik 7206(GUL 13/24/37/12-17); MK.G. 6(10), 19, 32, 34, 88, 150, 162, A.Özçelik (GUL 13/24/37-39); A.Ç., Muca \& Özçelik 03(GUL 13/24/37/1837); Özçelik 12773(GUL 13/24/37-b/01-03); Tatlı 4914, (GUL 13/24/37-38); MK. G. 83(GUL 13/24/37-39); MK. G.296, 318(GUL 13/24/37-38); A. Özçelik ÇGG.108(GUL 13/24/37-38); Özçelik 6487(GUL 13/24/37-39); A. Özçelik Ç.G.G. 106 (GUL 13/24/37-40). 

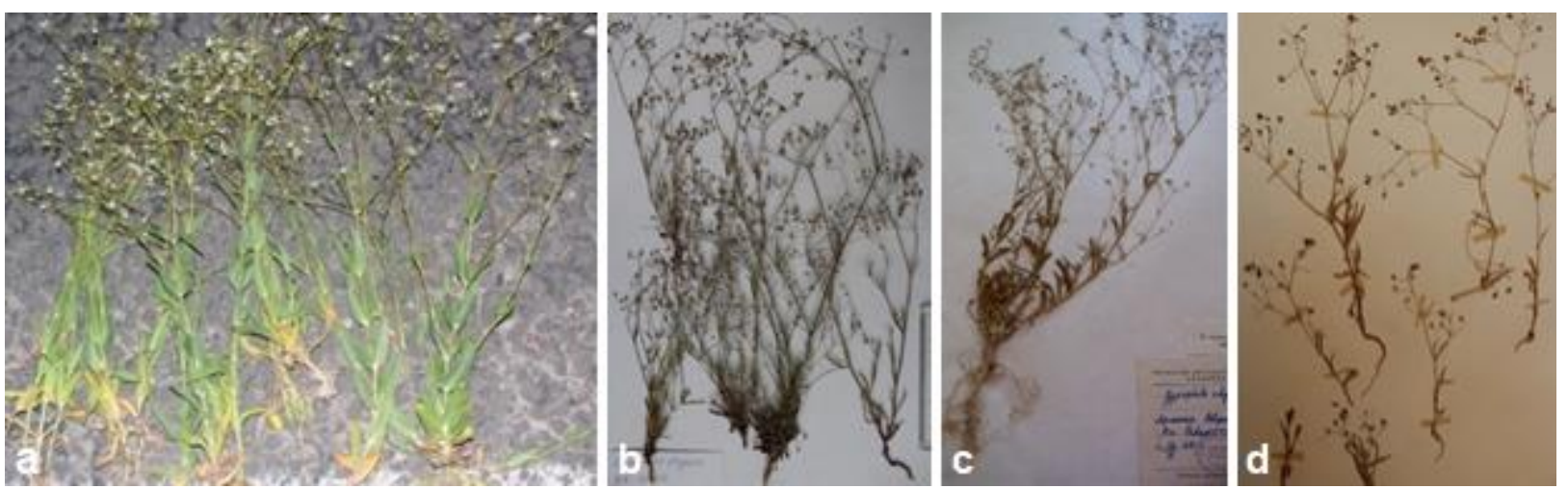

Figure 3. Gypsophila elegans (a: habit; b:MK. G. 339; c and d: Tatl1 4914).

Only Group Sarkis of G. bitlisensis can't be distinguished clearly from $G$. elegans. It may be a hybrid of G. elegans and G. bitlisensis. The Lake Van basin is a difference center of these species. For this reason, variation is very high in the species. Though each of the above mentioned types can taxonomically be thought as a variety, such a process has no contribution to systematics. These differences arise from the ecological features of the geography in which it is located. Distributed in Van, Ağrı, Bayburt, Erzurum, Artvin, Ardahan.

Gypsophila bitlisensis and G. elegans show a significant distribution. Gypsophila bitlisensis often occupies large areas in the Lake Van basin and dominantly grows in the area. A comparison of the two species is given in Table 1 .

Among our collections, a large number of the samples belonging to both $G$. elegans and $G$. bitlisensis were observed to grow in the region. These specimens are:

A8 Prov. Erzurum: Tortum, $4 \mathrm{~km}$ to Aksu, roadsides, 2250 m, 5 vii 1975, Tatl $2076.5 \mathrm{~km}$. from Karakurt to Horasan, roadsides and on moving rough stones, $1600 \mathrm{~m}$., 10 vi 1983, Tatlı 6923. Near Horasan borderland from Ağrı, roadsides and steppe, \pm 1950 m, 21 vii 1990, Özçelik 2264.

A9 Prov. Artvin: Artvin to Ardahan, $7 \mathrm{~km}$ from Yalnızçam pass, 2250 m, 4 viii 1973, EGE 13600. Erzurum: Şenkaya, Gülveren village, steppe, 2500 m, 20 viii 1982, Frrat Univ. 2894. Kars: 8 km from Kars to Ardahan, steppe, roadsides,
1800 m, 10 vii 1975, Tatlı 2680; Ardahan: 32 km from Göle to Ardahan, pastures, 2060 m, 8 vii 1975, Tatlı 2451.

B9 Prov. Ağrı: Eleşkirt, Tahir Mountains, S of Naziktepe, stony steppe, 1940 m, 10 vii 1994, Özgökçe 1970; Özçelik 3151; 3153. Bitlis: Tatvan Nemrut Lake, volcanic rocky places, ca. 2250 m, 5 vii 1986, EGE 33216. Van: W slope of Büyük Erek Mountain, steppe, 2100-2200 m, 6 viii 1989, Özçelik 295; 1113, 1299, EGE 32327. N of Beyüzümü village, sandy-stony steppe, 1750 m, 31 vii 1994, Özgökçe 1971. Özalp, Muhammed valley, steppe and roadsides, 1800 m, 2 viii 1994, Özgökçe 1972.

Gyprosphila bitlisensis: Erzurum-Ağr1; Bitlis/Tatvan, Erzurum/ Aşkale Sivas /Zara Erzurum/Horasan Refahiye, Erzincan; Its roots are perennial; Özçelik 5173 (GUL 13/24/37-3); Bitlis/Ahlat-Adilcevaz. Identification of it is problematic and suspicious. Mixed with G. elegans. MK. G. 83 (GUL 13/24/37-39). An interesting example, like perennial and multi-branched from the base. MK. G.296, 318; Erzurum-Ağrı: A. Özçelik (GUL 13/24/37-38); A Özçelik ÇGG.108(GUL 13/24/37-38); Özçelik 6487(GUL 13/24/37-39); A. Özçelik Ç.G.G.106 (GUL 13/24/37-40); Refahiye, $50 \mathrm{~km}$ to Erzincan, 13.7.2007; Bitlis/AhlatAdilcevaz; Bitlis/Tatvan, Erzurum/Aşkale.

Notes: Specimens, collected from Sivas/Zara Erzurum/Horasan and vouchered as MK.G.162 had very thin branches and sparsely flowered, a weak plant, a new population. Lower part of the plant is thickened, like a biennial or perennial (Fig. 4).

Table 1. A taxonomic comparison of G. elegans and G. bitlisensis (Özçelik and Özgökçe 1999)

\begin{tabular}{|l|l|l|}
\hline \multicolumn{1}{|c|}{ Characters } & \multicolumn{1}{|c|}{ G. elegans } & \multicolumn{1}{c|}{ G. bitlisensis } \\
\hline Habit & $\begin{array}{l}\text { Up to } 80 \mathrm{~cm} \text { tall, branched from upper part or near } \\
\text { it, rarely unbranched; an or a few main stemmed }\end{array}$ & $\begin{array}{l}\text { Up to 50 cm tall, always branched from the base, } \\
\text { Often many stemmed }\end{array}$ \\
\hline Leaves & 10 - 60 x 1-15 mm & $10-40 \mathrm{x} \mathrm{1-8} \mathrm{mm}$ \\
\hline Branching & Often clearly dichotomously branched & Many branched, weakly dichotomously branched \\
\hline Inflorescence & $\begin{array}{l}\text { Often diffuse, lax, less-flowered dichasium finer } \\
\text { branched and sparse flowering }\end{array}$ & $\begin{array}{l}\text { Large, dense, many-flowered dichasium } \\
\text { Thicker branched and many-flowered }\end{array}$ \\
\hline Bracts & Linear-oblong to ovate-triangular & Ovate-triangular \\
\hline Pedicels & 5-20 (-35) mm often longer than G. bitlisensis & 5-25 mm \\
\hline Calyx & 3-4 mm long & 2-3.5 (-4) mm long \\
\hline Petals & $\begin{array}{l}\text { 4-8(-10) mm; } \\
\text { broadly oblong to cuneate, emarginate }\end{array}$ & $\begin{array}{l}\text { 3.5-6 mm; } \\
\text { linear-oblong }\end{array}$ \\
\hline Seeds & With obtuse tubercles, a little & With minute obtuse tubercles, very much \\
\hline Habitat & $\begin{array}{l}\text { Slopes, steppe, gravel banks, roadsides, open } \\
\text { woodland }\end{array}$ & Steppe, slopes, rarely stream sides \\
\hline Distribution & $\begin{array}{l}\text { East and North parts of east Anatolia in Turkey } \\
\text { from sea level to 650-2600 m }\end{array}$ & $\begin{array}{l}\text { Endemic to Van Lake basin and its environs, from } \\
\text { sea level to 1650-1800 m }\end{array}$ \\
\hline
\end{tabular}




\subsubsection{Gypsophila heteropoda Freyn \& Sint.}

MK.G.314 (GUL 13/24/32-1); MK. 49 (GUL 13/24/33/209).

Two varieties of this species exist in Turkey. However, in Flora of Turkey (Davis 1967), the key is inadequate to identify these two varieties. Korkmaz (2011a) made a revision of annual Gypsophila species in Turkey, but the taxonomic problems of this species could not be adequately resolved, and a detailed study is necessary about this species. These variants can be distinguished with the key given below:

1. Plant densely branched and stems viscose with sessile glands. .var. heteropoda

1. Plant delicate, sparsely branched and glandular hairy, never viscose with sessile glands var minutiflora

Gyprosphila heteropoda Freyn \& Sint subsp. heteropoda: A9 Prov. Iğdır and B10 Prov. Ağri: This taxon was collected by us from many localities. Taxonomically confused with G. parva.

Gyprosphila heteropoda Freyn \& Sint subsp. minutiflora Barkoudah: It is known only from the collections made from Prov. Sivas. It is seen in rocky, arid areas. In the Flora of Turkey (Davis, 1967), it recorded as subsp. minutiflora Bark. Obviously, it is rare endemic and Ir.-Tur. el. (Figure 5).

\subsection{Revision of Gypsophila in the Group A of Turkey's Flora}

Group A comprises only annuals. During preparation of the illustrated Flora of Turkey, this grouping might very important. However, for most species, some important diagnostic characters such as inflorescence type, fruit shape, and number of ovules are still missing. Some of these shortcomings have been completed in this study. The definition of the sections will remain weak without removing these deficiencies. After that, species identification keys related to the sections should be made and the group key in Flora of Turkey (Davis, 1967) should be abandoned.

\subsubsection{Revised grouping of Gypsophila members in Turkey}

1.Annual herbaceous, without woody roots and vegetative stems. Group A

1.Biennial or perennial herbaceous, with woody roots and vegetative stems Groups B, C, D
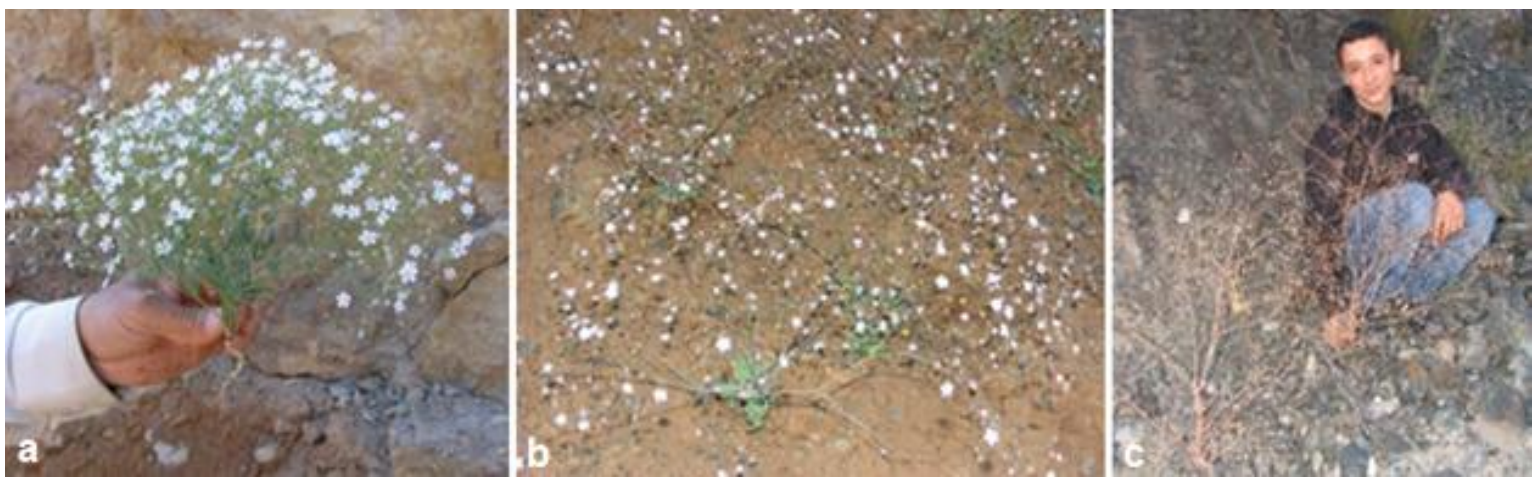

Figure 4. Variations in Gypsophila bitlisensis (a-c: habit)
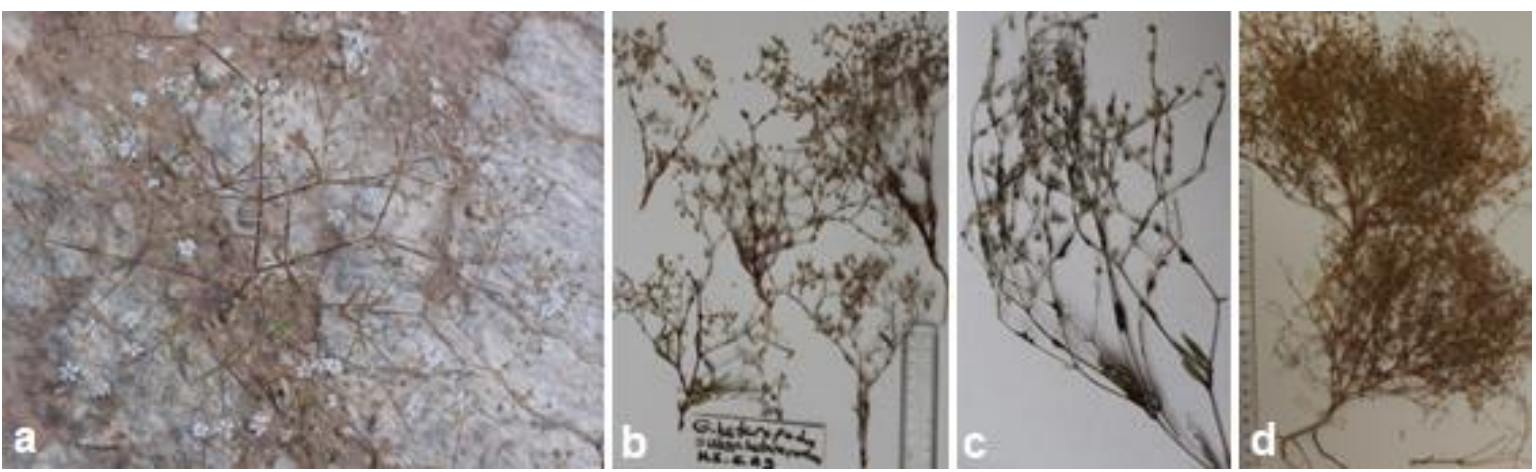

Figure 5. Gypsophila heteropoda (a: subsp. minutiflora; b and c: subsp. heteropoda; d: G. parva)

\subsubsection{Revised identification key for annual Gypsophila members (Group A) in Turkey by taking advantage of Davis (1967).}

1. Stem (at least at the base) and calyx hairy

2. Calyx pilose hairy (stem and leaves densely pilosevillose), leaves lanceolat, 10-30(-40) $\mathrm{mm}$ wide......pilosa

2. Calyx pilose not hairy, leaves linear, oblanceolate, up to $4 \mathrm{~mm}$ wide
3. Calyx tubulate, $4-8 \mathrm{~mm}$, petals $5-10(-12) \mathrm{mm}$ long

4. Pedicels 5.0-15.0 mm, inflorescence lax, bracts not leaf like

tubulosa

4. Pedicels 1.0-2.0 mm, inflorescence densely globose, bracts leaf like confertifolia

3. Calyx campanulate, up to $4.0 \mathrm{~mm}$, petals $2-5(-6) \mathrm{mm}$ long 
5. Bracts foliaceus, linear or oblanceolate, petals linear, cuneate, emarginate to bilobed

6. Pedicels 5-10 mm, petals 3-6 mm, cuneate, whitish or pink torulensis

6. Pedicels $10-20 \mathrm{~mm}$, petals $2-3.5 \mathrm{~mm}$, linear, white linearifolia

5. Bracts scarious, triangular, petals oblanceolate, acute to obtuse

7. Seeds obtus to acute tubercles; bracts and calyx glandular pubescent

heteropoda subsp. minutiflora

7. Seeds sharply echinate (prickly), bracts and calyx glabrous. parva

1. Stem (at the base) and calyx never hairy or viscous

8. Pedicels not capillary, leaves \pm oblanceolate rarely linear-lanceolate,

9. Whole plant viscous, leaves 3-5 non-apparent veined viscosa

9. The plant never viscous, leaves 1-3 distinctly grained

10. Petals oblanceolate to cuneate, bracts triangular, acute. heteropoda subsp. heteropoda

10. Petaller linear-oblong, bracts ovate-triangular, obtuse

11. Seeds obtuse bulging prominent tubercles, main stem dominant, 1 (-2), inflorescence loose dichasium .................................................elegans

11. Seeds long flat tubercles, main stem usually numerous, inflorescence frequent dichasium bitlisensis

8. Pedicels capillary, leaves linear to lanceolate

12. Bracts linear to lanceolate, leafy, calyx $2.5-4.8 \mathrm{~mm}$

13. Seeds flat tubercles, petals cuneate, calyx 2.5-4.0 $\mathrm{mm}$

14. Pedicels $5-10 \mathrm{~mm}$ (show only distributed in Tekirdağ for Turkey muralis

14. Pedicel 10-25 mm (only shows distribution in Şanlıurfa in Turkey antari

13. Seeds acute tubercles, petals linear-oblong, calyx $3.0-4.8 \mathrm{~mm}$ munzurensis

12. Bracts triangular, scarious, calyx $1.5-2.5 \mathrm{~mm} . . . .$. heteropoda subsp. heteropoda

\section{Conclusions and Suggestions}

In this study, it has been tried to solve taxonomic problems of some Turkish Gypsophila members.

1. Actual list of Turkey Gypsophila taxa and their sections have determined and correctly named taxa and sections (Table 2). While preparing this list in the light of observations and literature, contributions to solve of taxonomic problems, examined voucher specimens and important results are mentioned. In addition, all Gypsophila taxa have ranked on sections on the basis of kinship. Table 2 will not only be a check list of studies on Gypsophila taxa, but also it will be a scientific infrastructure showing the systematic location and correct naming of taxa.

2. In the all Floras books, large genera mainly are classified into sections. In the Flora of Turkey (Davis, 1967; Davis et al., 1988) too, this is the case. However, this principle was not applied in Gypsophila genus. Because the sections were not defined at the time of writing the Flora of Turkey (1967), the taxa could not be placed in the sections. Many new taxa have been recorded since then. These taxa had to be placed in their sections before starting the revision. For this reason, all Gypsophila taxa are classified in 4 large groups. It is an artificial but practical classification. Annual Gypsophila taxa were collected in Group A. B, C and D Groups include the perennial taxa.

3. We have been studying on the Gypsophila revision since 1993 (Özçelik and Özgökçe, 1995; 1999; Korkmaz and Özçelik, 2011a; Özgökçe et al., 2012; Fidan and Özgökçe, 2014; Armağan et al., 2017; Armağan and Özgökçe, 2018). We started from annual Gypsophila which a group of clear boundaries, and in this study, we prepared an identification key for annual members of the genus. To make this key, we were identified firstly problematic species, after their taxonomic problems were solved. Then species identification key was made.

4. There are two subspecies of $G$. heteropoda. These are $G$. heteropoda subsp. heteropoda and G. heteropoda subsp. minutiflora. G. heteropoda subsp. minutiflora appears to be a taxon far from the other taxon (subsp. heteropoda). For this reason, it should be increased to the statu of species category. However, its status has not been changed. Because it mixes with G. parva. If more detailed studies are conducted, if the difference can be clearly distinguished from G. parva, it can be promoted to the species category.

5. Another problem group is complex of G. elegans with $G$. bitlisensis. This complex group is partially mixed with $G$. viscosa. This confusion was fixed with the new key. All hesitant populations between G. elegans and G. bitlisensis were examined, after their species and populations were distinguished. Three groups of G. bitlisensis have been appeared. These groups might be called varieties or they might be called new species. But for now it has been called the group and the diagnostic key has been made. $G$. munzurensis is close to G. elegans, not to G. pilosa. The reason for the author to make this mistake is that G. elegans is not clearly defined.

6. Although a large number of Gypsophila taxa have been studied, revision of annuals is given in this study. A new subspecies of G. venusta species (subsp. staminea Özçelik and Özgökçe) have been added from perennial Gypsophila members.

7. The Gypsophila list of Turkey was updated. It has 63 Gypsophila species.

8. Gypsophila erikii Yild. (Yıldırıml1, 2012) and $G$. gracilescens Schischke's presence (Davis 1967) in Turkey is doubtful. The existence of G. laricina Schreb. (Sin.: Gypsophila sphaerocephala Fenzl ex Tchihat. Asie Min., Bot. 1: 205 (1860)) was confirmed. Some taxa of it are still known from type collection and some are relict. Some observations about taxonomic and geographical characters of all taxa are stated in a list of them.

Taxonomical and distributional data are unsatisfactory for Turkey. For floristic studies, few collections (of which some are new species or records) have been made from some mountains in the region by other botanists (Güner, 1983; Vural and Tan, 1983; Tan, 1984; Alpınar, 1994; Barrera et al., 1999; Y1ldırımlı, 2012; Armağan, 2016; 
Table 2. Updated Gypsophila species of Turkey and their investigated collections and some characteristics

\begin{tabular}{|c|c|c|c|c|}
\hline Taxon & Endemism & Distribution area & $\begin{array}{l}\text { Phytogeogra- } \\
\text { phical region }\end{array}$ & $\begin{array}{l}\text { Taxonomic situation, distribution and investigated } \\
\text { collections }\end{array}$ \\
\hline \multicolumn{5}{|c|}{ 1. Sect. Excapae Williams } \\
\hline $\begin{array}{l}\text { *1. G. serpylloides } \\
\text { Boiss. \& Heldr. }\end{array}$ & Endemic & C4 Antalya & $\begin{array}{l}\text { E. Medit.Mt. } \\
\text { el }\end{array}$ & $\begin{array}{l}\text { It is easily distinguished by its short creeping stems. } \\
\text { Özgökçe } 3173,3175 \text {. }\end{array}$ \\
\hline $\begin{array}{l}\text { *2. G. peshmenii } \\
\text { Güner }\end{array}$ & Endemic & B9 Bitlis & Ir.-Tur el. & - \\
\hline $\begin{array}{l}\text { 3.G. adenophylla } \\
\text { Barkoudah }\end{array}$ & Endemic & $\begin{array}{l}\text { B7 Erzincan?; } \\
\text { B9 Bitlis, Van; } \\
\text { C9 Hakkari }\end{array}$ & Ir.-Tur el. & $\begin{array}{l}\text { Recorded from Erzincan (Kandemir and Türkmen, } \\
\text { 2008) suspect. }\end{array}$ \\
\hline $\begin{array}{l}\text { 4. G. pulvinaris Rech. } \\
\text { f. }\end{array}$ & & A10 Ağr1 & & - \\
\hline $\begin{array}{l}\text { *5. G. hakkiarica Kit } \\
\text { Tan }\end{array}$ & Endemic? & C10 Hakkari & Ir.-Tur el. & - \\
\hline $\begin{array}{l}\text { 6. G. briquetiana } \\
\text { Schischk. }\end{array}$ & Endemic & $\begin{array}{l}\text { B7 Erzincan, Tunceli; } \\
\text { B8 Erzurum }\end{array}$ & Ir.-Tur el. & - \\
\hline \multicolumn{5}{|c|}{ 2. Sect. Gypsophila } \\
\hline $\begin{array}{l}\text { *7. G. davisii } \\
\text { Barkoudah }\end{array}$ & Endemic & C2 Muğla & $\begin{array}{l}\text { E. Medit.Mt. } \\
\text { el. }\end{array}$ & - \\
\hline \multicolumn{5}{|c|}{ 3. Sect. Ensifoliae Bark. } \\
\hline $\begin{array}{l}\text { *8. G. graminifolia } \\
\text { Barkoudah }\end{array}$ & Endemic & $\begin{array}{l}\text { A8 Erzurum; } \\
\text { B9 Van }\end{array}$ & Ir.-Tur. el. & $\begin{array}{l}\text { Local endemic Başkale (Van) city and its environs. } \\
\text { Erzurum record of it is new. }\end{array}$ \\
\hline \multicolumn{5}{|c|}{ 4. Sect. Corymbosae Barkoudah } \\
\hline *9. G. patrinii Seringe & & B10 Ağr1 & Ir.-Tur. el. & $\begin{array}{l}\text { It is written as a new record for Turkey. G. patrinii is } \\
\text { the synonym of this species (Armağan et al., 2017). }\end{array}$ \\
\hline $\begin{array}{l}\text { *10. G. brachypetala } \\
\text { Trautvetter }\end{array}$ & Endemic & A9 Kars & $\begin{array}{l}\text { Euro.-Sib. } \\
\text { el. }\end{array}$ & $\begin{array}{l}\text { It was written as Blacksea Mt. el. (Güner 2012) and G. } \\
\text { brachypetala Trautv. (Davis, 1967). } \\
\text { Özçelik \& A.Çelik 23 (GUL 13/24/6/1-4); Özçelik \& } \\
\text { A.Ç. } 27 \text { (GUL 13/24/6-5). }\end{array}$ \\
\hline $\begin{array}{l}\text { 11. G. guvengorkii } \\
\text { Armağan, Özgökçe \& } \\
\text { Çelik }\end{array}$ & Endemic & A4 Karabük & $\begin{array}{l}\text { Euxine (Mt.) } \\
\text { el }\end{array}$ & - \\
\hline $\begin{array}{l}\text { 12. G. yusufeliensis } \\
\text { Budak }\end{array}$ & Endemic & A8 Artvin & Ir.-Tur. el. & - \\
\hline $\begin{array}{l}\text { 13. G. transcaucasica } \\
\text { Barkoudah }\end{array}$ & & B9 Ağr1 & Ir.-Tur el. & $\begin{array}{l}\text { Only recorded in Doğubeyazit (A } \breve{g r} 1) \text {. Detailed } \\
\text { research is required to deduct taxonomic status. }\end{array}$ \\
\hline $\begin{array}{l}\text { 14. G. tenuifolia } \\
\text { M.Bieb. }\end{array}$ & & $\begin{array}{l}\text { A8 Artvin, } \\
\text { A9 Ardahan }\end{array}$ & $\begin{array}{l}\text { Euxine (Mt.) } \\
\text { el }\end{array}$ & It's a rare species. Taxonomically very problematic. \\
\hline \multicolumn{5}{|c|}{ 5. Sect. Capituliformes Williams. } \\
\hline $\begin{array}{l}\text { 15. G. glomerata Pall. } \\
\text { ex Adams }\end{array}$ & & A1 Tekirdağ & $\begin{array}{l}\text { Euxine (Mt.) } \\
\text { el. }\end{array}$ & $\begin{array}{l}\text { It was written as G. glomerata Adams by Güner } \\
\text { (2012). It is rare in Turkey. G. glomerata Pall. ex } \\
\text { Adams is considered as a valid name by the } \\
\text { international websites (Anonymous, 2020a,b). } \\
\text { New record is a species, very narrow range in Turkey, } \\
\text { rare. Edirne, from Süloğlu to Lalapaşa, Süloğlu exit, } \\
\text { MK. 1971, 1978; A.Ç. } 88 \text {. }\end{array}$ \\
\hline $\begin{array}{l}\text { 16. G. syriaca } \\
\text { Schischk. }\end{array}$ & Endemic & C6 Adana & $\begin{array}{l}\text { E.Medit.Mt. } \\
\text { el. }\end{array}$ & $\begin{array}{l}\text { It was a variety of G. sphaerocephala. It had been } \\
\text { removed from the synonym, but the synonym made } \\
\text { valid again as the species. It was more appropriate to } \\
\text { have a subspecies. According to Davis (1967), it is an } \\
\text { element of Ir.-Tur. region. }\end{array}$ \\
\hline $\begin{array}{l}\text { *17. G. pilulifera } \\
\text { Boiss. \& Heldr. }\end{array}$ & Endemic & $\begin{array}{l}\text { B5 Kırşehir, Nevşehir; } \\
\text { B7 Erzincan; } \\
\text { C3/ C4 Antalya }\end{array}$ & \begin{tabular}{|l|} 
E. \\
Medit.Mt. el.
\end{tabular} & $\begin{array}{l}\text { The distribution area of this species tends to expand } \\
\text { over time. Özçelik 1002, 1003(GUL 13/24/9/3-4); } \\
\text { A.Özçelik (GUL 13/24/9/1-2; Özçelik 1001(GUL } \\
\text { 13/24/9-5); Özçelik \& Muca 2013(GUL 13/24/9-6); } \\
\text { Dönmez 13754 B. Mutlu T. Ağar (İnönü Univ. Hb. } \\
\text { 728); } \\
\text { A. Özçelik (GUL 13/24/9/1-2; Özçelik 1002, } \\
\text { 1003(GUL 13/24/9/3-4; Özçelik 1001(GUL 13/24/9-5; } \\
\text { Özçelik \& Muca 2013(GUL 13/24/9-6); A. Özçelik } \\
\text { ÇG.18 (GUL 13/24/9-7); MK. 2104(GUL 13/24/9/8- } \\
\text { 10); Muca 15(GUL 13/24/9/11-12; A.Ç.01 (GUL } \\
\text { 13/24/9/13-20). }\end{array}$ \\
\hline $\begin{array}{l}\text { *18. G. olympica } \\
\text { Boiss. }\end{array}$ & Endemic & A2 Bursa & $\begin{array}{l}\text { E. Medit.Mt. } \\
\text { el }\end{array}$ & - \\
\hline $\begin{array}{l}\text { 19. G. pinifolia } \text { Boiss. } \\
\text { \& Hausskn. }\end{array}$ & Endemic & $\begin{array}{l}\text { B6 Malatya, K. Maraş; } \\
\text { B7 Malatya, Elazı̆g; } \\
\text { B8 Erzurum }\end{array}$ & Ir.-Tur. el. & $\begin{array}{l}\text { It can be distinguished by its leaves being pointed and } \\
\text { stinging. }\end{array}$ \\
\hline $\begin{array}{l}\text { *20. G. leucochlaena } \\
\text { Hub.-Mor. }\end{array}$ & Endemic & B6 Malatya, Sivas & Ir.-Tur. el. & $\begin{array}{l}\text { Between Gürün and Darende is the most important } \\
\text { habitat area of the species. }\end{array}$ \\
\hline
\end{tabular}




\begin{tabular}{|c|c|c|c|c|}
\hline & & & & Özçelik 12209 (GUL 13/24/12/ 1-5). \\
\hline $\begin{array}{l}\text { 21. G. osmangaziensis } \\
\text { Ataşlar \& Ocak } \\
\end{array}$ & Endemic & $\begin{array}{l}\text { B2 Kütahya, } \\
\text { B3Eskişehir }\end{array}$ & Ir.-Tur. el. & - \\
\hline 22. G. laricina Schreb. & Endemic & $\begin{array}{l}\text { B6 Tokat, } \\
\text { B8 Erzurum }\end{array}$ & Ir.-Tur. el. & $\begin{array}{l}\text { G. sphaerocephala Fenzl ex Tchihat. var. } \\
\text { cappadocica Boiss. was made synonym to this } \\
\text { species. Detailed taxonomic study required. The } \\
\text { spread of var. cappadocica is also spreading area of } \\
\text { this species. }\end{array}$ \\
\hline \multicolumn{5}{|c|}{ 6. Sect. Rokejeka (Forssk.) A. Braun. } \\
\hline $\begin{array}{l}23 a . \text { G. } \\
\text { paniculata } \mathrm{L} \text {. } \\
\text { var. araratica Hub.- } \\
\text { Mor. }\end{array}$ & Endemic & A9/A10 Iğdır, Ağrı & Ir.-Tur. el. & Endemic to Mount Ağrı. A rare species. \\
\hline $\begin{array}{l}\text { 23b. G. } \\
\text { paniculata } \mathrm{L} . \\
\text { var. paniculata }\end{array}$ & & Culture form & - & $\begin{array}{l}\text { This subspecies is being recorded for the first time for } \\
\text { Turkey. It is produced by florists in Izmir, Istanbul, } \\
\text { Yalova and Antalya for ornamental and landscape } \\
\text { purposes. Its origine is unknown. }\end{array}$ \\
\hline $\begin{array}{l}\text { 24. G. bicolor (Freyn. } \\
\text { \& Sint. Grossh. }\end{array}$ & & $\begin{array}{l}\text { A8 Artvin; } \\
\text { B8 Erzurum; B9 Van, } \\
\text { Bitlis, Iğdır, Kars }\end{array}$ & Ir.-Tur. el. & $\begin{array}{l}\text { The population has weakened due to excessive } \\
\text { collection. Van lake Basin is an important spread area. } \\
\text { It is abundant in parts of Azerbaijan near Iran and } \\
\text { Turkey. }\end{array}$ \\
\hline $\begin{array}{l}\text { 25. G. arrostii Guss. } \\
\text { var. nebulosa (Boiss. } \\
\text { \& Heldr.) Greuter \& } \\
\text { Burdet }\end{array}$ & Endemic & $\begin{array}{l}\text { B2 Manisa; B3 } \\
\text { Afyonkarahisar; } \\
\text { B4 Ankara; C2 Burdur, } \\
\text { Uşak, Denizli; C3 } \\
\text { Konya/ Isparta/ Burdur }\end{array}$ & Ir.-Tur. el. & $\begin{array}{l}\text { It is endemic to the Lakes Region. It is endemic to the } \\
\text { Lakes Region (Isparta, Burdur, Konya, } \\
\text { Afyonkarahisar, Denizli). }\end{array}$ \\
\hline $\begin{array}{l}\text { 26. G. simulatrix } \\
\text { Bornm. \& Woron }\end{array}$ & Endemic & $\begin{array}{l}\text { A8 Erzurum; A8/A9 } \\
\text { Artvin; A9 } \\
\text { Kars/Ardahan; B5 } \\
\text { Niğde; B6 Sivas; B6/B7 } \\
\text { Malatya C4 Konya; C3 } \\
\text { Afyonkarahisar } \\
\end{array}$ & Ir.-Tur. el. & $\begin{array}{l}\text { The phytogeographic region is specified for the first } \\
\text { time. It is the endemic of the Eastern Black Sea Region } \\
\text { and its environs. Its spread in Central Anatolia is } \\
\text { interesting. Thus, the area of soaking has expanded. } \\
\text { These examples and their land should be examined in } \\
\text { detail. }\end{array}$ \\
\hline $\begin{array}{l}\text { 27. G. baytopiorum } \\
\text { Kit Tan } \\
\end{array}$ & Endemic & C9 Hakkari & Ir.-Tur. el. & - \\
\hline $\begin{array}{l}\text { 28a. G. perfoliata L. } \\
\text { var. perfoliata }\end{array}$ & & $\begin{array}{l}\text { B3 Afyonkarahisar; } \\
\text { B4 Ankara/ Konya, } \\
\text { Kayseri; } \\
\text { B5 Kayseri; } \\
\text { B6 Sivas; } \\
\text { B7 Erzincan; } \\
\text { C2 Denizli; } \\
\text { C4 Konya } \\
\end{array}$ & Ir.-Tur. el. & $\begin{array}{l}\text { This taxon was newly created for Turkey. Before, there } \\
\text { was only G. } p \text {. var. araratica. Its habitus is variable. It } \\
\text { is a very polymorphic species. Their forms could be } \\
\text { seen between Afyonkarahisar, Eskişehir and Ankara. It } \\
\text { is easily distinguished by its large layers of flowers and } \\
\text { strong plant. It is also produced by florists in Antalya, } \\
\text { Izmir, Manisa vilayets etc. There are culture and wild } \\
\text { forms. }\end{array}$ \\
\hline $\begin{array}{l}\text { 28b. G. perfoliata L. } \\
\text { var. araratica Kit Tan }\end{array}$ & Endemic ? & $\begin{array}{l}\text { A9 Erzurum-Ağrı } \\
\text { B9/10 Iğdır }\end{array}$ & Ir.-Tur. el. & $\begin{array}{l}\text { It is endemic to the Ağrı mountain Its endemicity to } \\
\text { Turkey section of Mount Ağrı is controversial. It is } \\
\text { unknown presence in the part that does not belong to } \\
\text { Turkey of the mount. The accuracy of the taxon is } \\
\text { questionable. } \\
\text { It purchased from the Real Market/flower section. }\end{array}$ \\
\hline $\begin{array}{l}\text { *29. G. simonii Hub- } \\
\text { Mor. }\end{array}$ & Endemic & $\begin{array}{l}\text { A4 Çankırı; } \\
\text { B5 Yozgat/ Kayseri/ } \\
\text { Ankara; } \\
\text { B6 Sivas; } \\
\text { B7 Erzincan/ Malatya; } \\
\text { B9 Van/ Kars/ Iğdır; } \\
\text { C4 Konya. }\end{array}$ & Ir.-Tur. el. & $\begin{array}{l}\text { It spreads depending on gypsum rock. It is one of the } \\
\text { indicator plants of gypsum rocks. It is an endemic } \\
\text { specific to salty, gypseous areas around Çankırı. Rare } \\
\text { endemic. } \\
\text { A.Özçelik ÇGG. 61(GUL 13/24/18-1); A.Özçelik } \\
\text { ÇGG.46 (GUL 13/24/18-2); A.Özçelik ÇGG.99(GUL } \\
\text { 13/24/18-94); MK.48 (GUL 13/24/18/95-96. }\end{array}$ \\
\hline $\begin{array}{l}\text { 30. G. oblanceolata } \\
\text { Barkoudah }\end{array}$ & Endemic & $\begin{array}{l}\text { B4 Niğde/Aksaray/ } \\
\text { Konya }\end{array}$ & Ir.-Tur. el. & $\begin{array}{l}\text { The fleshy structure and oblanceolat shape of the } \\
\text { leaves is distinctive. It is peculiar to salty marshes in } \\
\text { the Middle Anatolian region. It mixes with } G \text {. } \\
\text { germanicopolitana in the identification key. Only the } \\
\text { leaves differed from G. germanicopolitana it may be } \\
\text { distribution. } \\
\text { M.K. } 67 \text { (GUL 13/24/18/01-02). }\end{array}$ \\
\hline $\begin{array}{l}\text { 31. G. } \\
\text { germanicopolitana } \\
\text { Hub.-Mor. }\end{array}$ & Endemic & $\begin{array}{l}\text { A4 Çankırı; } \\
\text { B5 Yozgat, Kırşehir; } \\
\text { B5/B6 Kayseri; Sivas }\end{array}$ & Ir.-Tur. el. & $\begin{array}{l}\text { It is grown on stony, loamy, sandy soils. It was a local } \\
\text { endemic known only from Çankırı. The distribution } \\
\text { area has been extended with new records. A.Özçelik } \\
\text { 116(GUL 13/24/20-1); A.Özçelik 207(GUL 13/24/20- } \\
\text { 2); A.Özçelik 43(GUL 13/24/20-3); A.Özçelik \& } \\
\text { K.Aydınşakir 03(GUL 13/24/20-4). }\end{array}$ \\
\hline $\begin{array}{l}\text { 32. G. nabelekii } \\
\text { Schischk. }\end{array}$ & & $\begin{array}{l}\text { B10 Iğdır; } \\
\text { C9/10 Hakkari }\end{array}$ & Ir.-Tur. el. & $\begin{array}{l}\text { Endemicity of it is controversial. Its spread can also } \\
\text { be found in Iraq. Its type specimen from Turkey. }\end{array}$ \\
\hline 33. G. curvifolia Fenzl & Endemic & $\begin{array}{l}\text { C3 Antalya, Isparta, } \\
\text { Burdur; }\end{array}$ & $\begin{array}{l}\text { E. Medit. } \\
\text { Mt. el. }\end{array}$ & $\begin{array}{l}\text { It grows in swamps and wetlands or on their edges. It } \\
\text { is an endemic to Lakes region. }\end{array}$ \\
\hline
\end{tabular}




\begin{tabular}{|c|c|c|c|c|}
\hline & & C4 Antalya, Konya & & $\begin{array}{l}\text { Özçelik 7335(GUL 13/24/22-1-5); MK. 897(GUL } \\
\text { 13/24/20-6); Özçelik 8038 (GUL 13/24/22/7-8) } \\
\end{array}$ \\
\hline $\begin{array}{l}\text { 34. G. festucifolia } \\
\text { Hub.-Mor. }\end{array}$ & Endemic & B6 Sivas, Kayseri & Ir.-Tur. el. & - \\
\hline $\begin{array}{l}\text { 35. G. turcica } \\
\text { Hamzaoğlu }\end{array}$ & Endemic & B6 Sivas & Ir.-Tur. el. & $\begin{array}{l}\text { It is a new recorded species known from type } \\
\text { gathering (Hamzaoğlu, 2012). }\end{array}$ \\
\hline $\begin{array}{l}\text { 36. G. libanotica } \\
\text { Boiss. }\end{array}$ & & $\begin{array}{l}\text { B6 Niğde; } \\
\text { C5 Konya, Niğde; } \\
\text { C6 K. Maraş, Osmaniye }\end{array}$ & $\begin{array}{l}\text { E. Medit. } \\
\text { (Mt.) el. }\end{array}$ & - \\
\hline $\begin{array}{l}\text { 37. G. ruscifolia } \\
\text { Boiss. }\end{array}$ & & $\begin{array}{l}\text { B7 Elazı̆̆ Tunceli; B8 } \\
\text { Erzurum, Muş; B9 Van, } \\
\text { Bitlis, Ağrı; C6 } \\
\text { Gaziantep; C8 } \\
\text { Diyarbakır, Mardin } \\
\end{array}$ & Ir.-Tur. el. & $\begin{array}{l}\text { It is easily distinguished by the perfoliate leaves. It is } \\
\text { common in East and South East Anatolian regions. Its } \\
\text { rhizomes are very flexible. }\end{array}$ \\
\hline 38. G. pallida Stapf. & & $\begin{array}{l}\text { B6 Kahramanmaraş, } \\
\text { Malatya, Elazığ; B9 } \\
\text { Van; C9 Hakkari }\end{array}$ & Ir.-Tur. el. & - \\
\hline $\begin{array}{l}\text { *39. G. tuberculosa } \\
\text { Hub.-Mor. }\end{array}$ & Endemic & B7 Erzincan & Ir.-Tur. el. & $\begin{array}{l}\text { Its identification is very difficult to make from the } \\
\text { current key. It mixes with Bolanthus, but it is annual. }\end{array}$ \\
\hline 40. G. aucheri Boiss. & Endemic & \begin{tabular}{|l|} 
B7Sivas/Erzincan/ \\
Tunceli, Malatya, \\
Adraman; B8 Erzurum \\
\end{tabular} & Ir.-Tur. el. & It spreads in environment peculiar to rock. \\
\hline 41. G. eriocalyx Boiss. & Endemic & $\begin{array}{l}\text { A4 Çankır1; A9 } \\
\text { Kars/Ardahan; B3 } \\
\text { Eskişehir; B4 Ankara; } \\
\text { B5 Kayseri/ Çorum; B6 } \\
\text { Sivas; C5 Niğde } \\
\end{array}$ & Ir.-Tur. el. & $\begin{array}{l}\text { Hair features in the stem, leaves, and calyx provide } \\
\text { important diagnostic characters. }\end{array}$ \\
\hline $\begin{array}{l}\text { *42. G. lepidioides } \\
\text { Boiss. }\end{array}$ & Endemic & B7 Erzincan & Ir.-Tur. el. & $\begin{array}{l}\text { It develops depending on gypsum rock, it shows local } \\
\text { distribution. It is endemic to Erzincan environment. It } \\
\text { is close to G. eriocalyx. is easily distinguished by its } \\
\text { inflorescence stalk and indumentum characters. } \\
\text { Özçelik 12876 (GUL 13/24/30/1-13). }\end{array}$ \\
\hline \multicolumn{5}{|c|}{ 7. Sect. Heterochroa (Bunge) Fenzl. } \\
\hline $\begin{array}{l}\text { 43. G. glandulosa } \\
\text { (Boiss.) Walp. }\end{array}$ & Endemic ? & $\begin{array}{l}\text { A7 Trabzon; } \\
\text { A8 Erzurum, Rize; } \\
\text { A9 Artvin } \\
\end{array}$ & $\begin{array}{l}\text { Euxine Mt. } \\
\text { el. }\end{array}$ & $\begin{array}{l}\text { It may be not endemic. Type specimen of it from } \\
\text { Turkey (Güner, 2012). }\end{array}$ \\
\hline \multicolumn{5}{|c|}{ 8. Sect. Dichoglottis (Fisch. \& Mey.) Fenzl } \\
\hline $\begin{array}{l}\text { 44a. G. heteropoda } \\
\text { Freyn \& Sint. } \\
\text { subsp. heteropoda }\end{array}$ & & $\begin{array}{l}\text { A9 Kars; } \\
\text { B10 Ağr1 }\end{array}$ & Ir.-Tur. el. & \multirow{2}{*}{$\begin{array}{l}\text { In identification, } 2 \text { subspecies seems to be impossible } \\
\text { with the existing key. A new key was made by us. } \\
\text { Subsp. heteropoda can be easily distinguished by } \\
\text { presence of viscous structures in stems and } \\
\text { inflorescences. But subsp. minutiflora is very difficult } \\
\text { to define. Detailed studies are needed. Subsp. } \\
\text { minutiflora may be a separate species. The taxon is } \\
\text { mixed with } G \text {. parva. The plant is completely hairless } \\
\text { and not viscos, it should be studied in detail, it does not } \\
\text { go from } 1 \text { st to } 1 \text { st, not from } 2 \text { nd to } 1 \text { st. Some have } \\
\text { viscosity, some do not. }\end{array}$} \\
\hline $\begin{array}{l}\text { 44b. G. heteropoda } \\
\text { Freyn \& Sint. } \\
\text { subsp. minutiflora } \\
\text { Barkoudah }\end{array}$ & Endemic & B6 Sivas & Ir.-Tur. el. & \\
\hline $\begin{array}{l}\text { 45. G. parva } \\
\text { Barkoudah }\end{array}$ & Endemic & $\begin{array}{l}\text { A4 Çankırı; } \\
\text { A5 Çorum }\end{array}$ & Ir.-Tur. el. & - \\
\hline $\begin{array}{l}\text { 46. G. linearifolia } \\
\text { (Fisch. \& C.A. Mey.) } \\
\text { Boiss. }\end{array}$ & & $\begin{array}{l}\text { B5 Nevşehir and its } \\
\text { environs }\end{array}$ & Ir.-Tur. el. & $\begin{array}{l}\text { Taxonomic features are not safe. It is particularly } \\
\text { confused with G. elegans. }\end{array}$ \\
\hline $\begin{array}{l}\text { 47. G. bitlisensis } \\
\text { Barkoudah }\end{array}$ & Endemic & \begin{tabular}{|l} 
B6/7 Sivas; B7 \\
Erzincan; B8 Erzurum; \\
B9 Bitlis, Van \\
\end{tabular} & Ir.-Tur. el. & - \\
\hline 48. G. viscosa Murr. & & $\begin{array}{l}\text { A9 Kars; Iğdır; B3 } \\
\text { Eskişehir; B4 Konya, } \\
\text { Ankara; B5 Kayseri; B6 } \\
\text { Sivas; C3 Konya, } \\
\text { Isparta; C6 Şanlıurfa } \\
\end{array}$ & Ir.-Tur. el. & - \\
\hline $\begin{array}{l}\text { 49. G. elegans M. } \\
\text { Bieb. }\end{array}$ & & $\begin{array}{l}\text { A7 Gümüşhane, } \\
\text { Bayburt; A8 Erzurum; } \\
\text { B7 Erzincan, } \\
\text { Diyarbakır; B9 Van, } \\
\text { Bitlis; B10 Kars, Iğdır, } \\
\text { Ağr1; C3/C4 Konya } \\
\end{array}$ & Ir.-Tur. el. & $\begin{array}{l}\text { The distribution area of the species is mainly in the } \\
\text { Eastern Anatolia region and it also spreads in the } \\
\text { Eastern Black Sea region close to this region. Steppe, } \\
\text { meadow and arid meadows are important habitats for } \\
\text { it. }\end{array}$ \\
\hline 50. G. silenoides Rupr. & & $\begin{array}{l}\text { A7 Giresun, } \\
\text { Gümüşhane, Trabzon; } \\
\text { A8 Trabzon, Rize, } \\
\text { Artvin; A9 Artvin; } \\
\text { Ardahan }\end{array}$ & Euxin el. & $\begin{array}{l}\text { It is usually biennial, rarely perennial. In the first year, } \\
\text { rosette leaves are formed, in the } 2 \text { nd year there is } \\
\text { flowering. If this condition is unknown, its } \\
\text { identification is difficult. The spreading area of the } \\
\text { species is essentially the Eastern Black Sea region. It is }\end{array}$ \\
\hline
\end{tabular}




\begin{tabular}{|c|c|c|c|c|}
\hline & & & & $\begin{array}{l}\text { the Kashgar mountains between Trabzon and Rize. It } \\
\text { grows abundantly on gravelly slopes. }\end{array}$ \\
\hline $\begin{array}{l}\text { 51. G. polyclada } \\
\text { Fenzl. ex Boiss. } \\
\end{array}$ & & C10 Hakkari & Ir.-Tur. el. & It is rare species. \\
\hline $\begin{array}{l}\text { 52. G. antari Post. \& } \\
\text { Beauverd. }\end{array}$ & & C7 Şanlıurfa & $\begin{array}{l}\text { Sahara } \\
\text { Arabian el. }\end{array}$ & $\begin{array}{l}\text { It is rare species. Especially in Akçakale, which is the } \\
\text { border of Syria, it has spread. }\end{array}$ \\
\hline \multicolumn{5}{|c|}{ 9. Sect. Marcrorhizaea Boiss. } \\
\hline 53. G. muralis L. & & A1 Edirne & $\begin{array}{l}\text { Euro.-Sib. } \\
\text { el. }\end{array}$ & $\begin{array}{l}\text { Its general appearance is similar to Arenaria genus. It } \\
\text { was recorded from Çörekköy (Davis 1967). Today, } \\
\text { Çörekköy is within the borders of Greece, } 13 \mathrm{~km} \text { away } \\
\text { from the Customs Gate of Pazarkule. It has been } \\
\text { revealed with the subsequent research that it has spread } \\
\text { in Tekirdağ / Silivri-Çorlu. It's a rare species. } \\
\text { Sammel 02.284(EGE); A.Özçelik (GUL 13/24/40-2 }\end{array}$ \\
\hline $\begin{array}{l}\text { *54. G. torulensis } \\
\text { M.Koç }\end{array}$ & & A7 Gümüşhane & $\begin{array}{l}\text { Euro.-Sib. } \\
\text { el. ? }\end{array}$ & It resembles to G. muralis (Koç 2013) \\
\hline $\begin{array}{l}\text { 55. G. tubulosa (Jaub. } \\
\text { \& Spach) Boiss. }\end{array}$ & Endemic & $\begin{array}{l}\text { B1 İzmir; } \\
\text { B2 Uşak; } \\
\text { C1/C2 Aydın } \\
\end{array}$ & E. Medit. el. & $\begin{array}{l}\text { It leaves from genus Bolanthus as it is annual. There is } \\
\text { also an example in IZEF Hb. (İzmir). It is a difficult } \\
\text { species to identification. }\end{array}$ \\
\hline $\begin{array}{l}\text { 56. G. confertifolia } \\
\text { Hub.-Mor. }\end{array}$ & Endemic & C2 Muğla, Burdur & E. Medit. el. & $\begin{array}{l}\text { This kind of short, dense flowered inflorescence looks } \\
\text { like Velezia. MK. } 16 \text { (GUL13/24/42-1) }\end{array}$ \\
\hline 57. G. hispida Boiss. & & $\begin{array}{l}\text { A8 Gümüşhane, } \\
\text { Erzurum; A9 Kars, } \\
\text { Iğdır; B7 Erzincan, } \\
\text { Tunceli; B8 Erzurum; } \\
\text { B10 Iğdır, Kars }\end{array}$ & Ir.-Tur. el. & $\begin{array}{l}\text { Type sample from Turkey. This species has not been } \\
\text { seen by us. }\end{array}$ \\
\hline \multicolumn{5}{|c|}{ 10. Sect. Hagenia A. Braun. } \\
\hline 58. G. pilosa Hudson & & 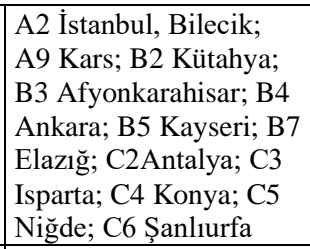 & Ir.-Tur. el. ? & $\begin{array}{l}\text { It is a species widespread throughout Turkey. It doesn't } \\
\text { choose many habitats. It must be a cosmopolitan } \\
\text { species. Özçelik \& Muca 05(GUL 13/24/44/02-09); } \\
\text { Özçelik \& Muca 12(GUL 13/24/44-10); Özçelik \& } \\
\text { Muca 04(GUL 13/24/44/11-16); Özçelik 12877(GUL } \\
\text { 13/24/44-17); Özçelik 12877(GUL 13/24/44-18); MK. } \\
\text { 704(GUL 13/24/44-19); MK. 700. }\end{array}$ \\
\hline $\begin{array}{l}\text { 59. G. munzurensis } \\
\text { Armağan }\end{array}$ & Endemic & B7 Tunceli & Ir.-Tur. el. & $\begin{array}{l}\text { It is seem like G. elegans not G. pilosa. (Armağan } \\
\text { 2016) }\end{array}$ \\
\hline $\begin{array}{l}\text { 60. G. nodiflora } \\
\text { (Boiss.) Barkoudah }\end{array}$ & Endemic & B7 Elazı̆̆ ; C6 Malatya & Ir.-Tur. el. & This species has not been seen by us. \\
\hline $\begin{array}{l}\text { 61a. G. venusta Fenzl } \\
\text { subsp. venusta }\end{array}$ & & $\begin{array}{l}\text { A4 Çankırı; A7 Sivas; } \\
\text { B3 Afyonkarahisar; B4 } \\
\text { Ankara, Konya; B5 } \\
\text { Yozgat, Kayseri; B6 } \\
\text { Sivas; B7 Malatya; B8 } \\
\text { Erzurum, Erzincan; C3 } \\
\text { Isparta, Konya, } \\
\text { Karaman; C5 Niğde; C6 } \\
\text { Gaziantep, Adana; C7 } \\
\text { Şanlıurfa }\end{array}$ & Ir.-Tur. el. & $\begin{array}{l}\text { The most distinctive feature of the length of the petals } \\
\text { and the high ratio of calyx. Subsp. venusta was named } \\
\text { for the first time. Although it is seen in the same region } \\
\text { with subsp. staminea, its main spreading area is the } \\
\text { Lakes Region and Central Anatolia Region. It is very } \\
\text { rare in Eastern Anatolia. }\end{array}$ \\
\hline $\begin{array}{l}\text { 61b. G. venusta Fenzl } \\
\text { subsp. staminea } \\
\text { Özçelik and Özgökçe }\end{array}$ & Endemic & Erzurum & Ir.-Tur. el. & $\begin{array}{l}\text { It is a rare endemic known from type gathering. Its } \\
\text { stamen characters is distinguished from subsp. } \\
\text { venusta. }\end{array}$ \\
\hline & & & & \\
\hline \multicolumn{5}{|c|}{$\begin{array}{l}\text { 62. G. gracilescens Schischk. (Davis 1967) and 63. G. erikii Yild. (Yıldırıml, 2012) are suspected of being in Turkey. Their samples } \\
\text { are not seen. }\end{array}$} \\
\hline
\end{tabular}

Armağan et al., 2017). General literatures (Rechinger, 1988; Karagüzel et al., 1992; Kandemir and Türkmen, 2008; Özçelik and Yıldırım, 2012; Anonymous, 2020c) which are still available are those primarily meant for the general systematic and taxonomy. For most of the plants described appears to us as invalid. In view of this, we have started investigation on the genus based on personal observations and wider collections on population basis.

Most of the investigated collections are dated after the publication of the Flora of Turkey, and some of them could not be distinguished from each other with the help of the Flora (Davis, 1967). Those taxa included in Güner (2012) were prepared more accurately. However, there is no identification key and also their Turkish names and geographical regions are dream, does not meet to the reality of Turkey in general. Some members of the genus show a great variation in indumentum, branching and flower number, due to polymorphism, hybridisation, polyploidy and habitat differences. As such, their taxonomical status has not been revealed fully.

While visiting the area, we came to conclusion that the region between Ağrı and Van, Bitlis especially Tahir, Tendürek, Süphan, Nemrut and Ağrı Mountains, Başkale environs appear to us as center of great diversity for the genus. The mountains and their environs are very rich in $G$. bitlisensis and $G$. elegans. The area should therefore be investigated in detail. 


\section{Conflict of Interest}

Authors have declared no conflict of interest.

\section{Authors' Contributions}

The authors contributed equally.

\section{Acknowledgments}

The examined materials in this study were collected by us within the scope of the following projects: TÜBİTAK,
TBAG 107T147 numbered Project; TÜBİTAK-DPT, TBAG. Ç. Sek. No:4; in 2006-2008 years, by TOVAG, titled Cut Flower Variety Development Project-Creating Gene Pools (Phase I); Süleyman Demirel Univ. Rectorate Research Fune Project 44; Yüzüncü Y1l University Rectorate, Research Fune, 2009-FBE- YL 011; 2011-FBED- 030; VET-2957. We thank to the relevant institutions and work teams. Also, we would like to thank the researchers and herbarium officers whose examples have been reviewed in the article.

\section{References}

Alpınar K (1994). Some Contributions to the Turkish Flora. Edinburgh Journal of Botany 51(1): 65-73.

Anonymous (2020a). http://www.theplantlist.org/tpl1.1/record/kew-2836684 [accessed 14 March 2020].

Anonymous (2020b). http://powo.science.kew.org/taxon/urn:lsid:ipni.org:names:154479-1 [accessed 05 April 2020].

Anonymous (2020c). https://www.gbif.org/species/155862787 [accessed 05 April 2020].

Armağan M (2016). Gypsophila munzurensis (Caryophyllaceae), a new species from Tunceli (Turkey). Phytotaxa 275(2): 175-180.

Armağan M, Özgökçe F, Çelik A (2017). Notes on the genus Gypsophila (Caryophyllaceae) in Turkey, with a description of $G$. guvengorkii sp. Nov. Phytotaxa 295(3): 271-275.

Armağan M, Özgökçe F (2018). Anatomical, Palynological, Morphological, Karyological, and Ecological Investigations on Gypsophila davisii. Anatolian Journal of Botany 2(1): 39-45.

Ataşlar E, Ocak A (2005). Gypsophila osmangaziensis (Caryophyllaceae), a new species from Central Anatolia, Turkey. Annales Botanici Fennici 42: 57-60.

Ataşlar E (2000). in edts: Güner A, Özhatay N, Ekim T, Başer KHC 2000. Flora of Turkey and the East Aegean Islands, Vol. 11. Edinburgh: Edinburgh University Press.

Barkoudah YI (1962). A Revision of Gypsophila, Bolanthus, Ankyropetalum and Phryna. Wentia 9: 1-203.

Barrera AC, Arenas G (1999). Cutting-time effect during harvest cycle on postharvest behavior of three Gypsophila paniculata cv. perfecta clones. Proc of the Int Symp on Cut Flowers in the Tropics. Acta Horticulturae 482: 71-76.

Budak Ü (2012). A new species of Gypsophila (Caryophyllaceae): Gypsophila yusufeliensis Budak, from Turkey. Annales Botanici Fennici 49: 425-427.

Davis PH (1967). Flora of Turkey and the East Aegean Islands, Vol. 2. Edinburgh: Edinburgh University Press.

Davis PH, Mill RR, Tan K (1988). Flora of Turkey and the East Aegean Islands, Vol. 10. Edinburgh: Edinburgh University Press.

Ekim T (2012). Gypsophila. Bizimbitkiler (2013). http://www.bizimbitkiler.org.tr [accessed 12 November 2020].

Fidan M, Özgökçe F (2014). Türkiye Gypsophila L. (Caryophyllaceae) cinsine iit Hagenia A. Braun., seksiyonunun polen ve tohum morfolojisi. 22. Ulusal Biyoloji Kongresi Eskişehir Osmangazi Üniversitesi, 537, $23-27$ Haziran 2014.

Fidan M, Özgökçe F (2016). Türkiye Gypsophila L. (Caryophyllaceae) cinsine iit Hagenia A. Braun. seksiyonunun revizyonu. Turkish Journal of Life Sciences 1(2): 75-85.

Güner A (1983). New records for the Flora of Turkey and two new species from Anatolia. Notes from the Royal Botanic Garden 41(2): 283-288.

Güner A (2012). Türkiye bitkileri listesi (Damarlı Bitkiler). ANG Vakfı Nezahat Gökyiğit Botanik Bahçesi Yayınları Flora Dizisi 1. İstanbul: NAMAŞ Nurtan Ambalaj ve Matbaacılık San ve Tic AŞ.

Güner A, Özhatay N, Ekim T, Başer KHC (2000). Flora of Turkey and the East Aegean Islands, Vol. 11. Edinburgh: Edinburgh University Press.

Hamzaoğlu E (2012). A new species of Gypsophila and a new name for Silene (Caryophyllaceae) from Turkey. Turkish Journal of Botany 36: 135-139.

Huber-Morath A, McNeill J, Reeve H (1967). Materials for a Flora of Turkey. XIV: Caryophyllaceae, Notes from the Royal Botanic Garden 27(1): 17-23.

Kandemir A, Türkmen Z (2008). The flora of Üzümlü-Sakaltutan (Erzincan-Gümüşhane). Turkish Journal of Botany 32: 265-304.

Karagüzel O, Altan S (1999). Gypsophila paniculata L. "Perfecta"nın büyüme ve çiçeklenmesi üzerine dikim zamanı ve gün uzunluğunun etkileri. Turkish Journal of Agriculture and Forestry 23(Ek Say1 2): 257- 280.

Koç M (2013). Gypsophila torulensis (Caryophyllaceae) a New Species from Turkey. Annales Botanici Fennici 50: 149-150.

Korkmaz M, Özçelik H (2011a). Systematical and morphological characteristics of annual Gypsophila L. (Caryophyllaceae) taxa of Turkey. Biological Diversity and Conservation 4(1): 79- 98.

Korkmaz M, Özçelik H (2011b). Economic importances of Gypsophila L., Ankyropetalum Fenzl and Saponaria L. (Caryophyllaceae) taxa of Turkey. African journal of Biotechnology 10(47): 9533-9541.

Koyuncu M, Kılıç CS, Güvenç A (2008). Soaproot yielding plants of East Anatolia and their potential in nature. Turkish Journal of Botany 32: 489-494. 
Linnaeus C (1753). Species plantarum: exhibentes plantas rite cognitas, ad genera relatas, cum differentiis specificis, nominibus trivialibus, synonymis selectis, locis natalibus, secundum systema sexuale digestas. Stockholm: Laurentius Salvius.

Özçelik H, Özgökçe F (1995). Taxonomic contributions to genus Gypsophila L. (Caryophyllaceae) from East Anatolia (Turkey). IV th Plant Life of South West Asia Symposium. 195-209, May 23-25 1995 İzmir Turkey.

Özçelik H, Özgökçe F (1999). Gypsophila bitlisensis Bark. ve Gypsophila elegans M. Bieb. üzerinde morfolojik, taksonomik ve ekolojik araştırmalar. 1st International Symposium on Protection of Natural Environment and Ehrami Karaçam 23-25th September 1999, Kütahya/Turkey 295- 313.

Özçelik H, Yıldırım B (2011). Türkiye çövenlerinin (Gypsophila L. ve Ankyropetalum Fenzl spp.) ekonomik önemi, kullanım olanakları ve korunması üzerine düşünceler. SDÜ Orman Fakültesi Dergisi 12: 57-61.

Özgökçe F, Fidan M, Armağan M (2012). Gypsophila nodiflora (Boiss.) Barkoudah (Caryophyllaceae) üzerine bazı araştırmalar, 21. Ulusal Biyoloji Kongresi. 14-22, 3-7 Eylül 2012 Ege Üniversitesi İzmir Türkiye.

Rechinger KH (1988). Gypsophila L., in Rechinger KH (ed.), Flora Iranica 163. Akademische Druck und Verlagsanstalt, Graz: 206-246.

Schischkin BK (1936). Gypsophila L., in Komarov VL (ed.), Flora of the U.S.S.R., Vol. 6. Leningrad: Izdatel' stvo Akademii Nauk SSSRR.

Tan K (1984). More new taxa from South and East Anatolia. Notes from the Royal Botanic Garden 42(1): 61-67.

Vural M, Tan K (1983). New taxa and records from Turkey. Notes from the Royal Botanic Garden 41(1): 65-67.

Yıldırımlı Ş (2012). Nine new species from Kaz dağları, Munzur dağları, Bolkar dağları and Karçal dağları Turkey. Ot Sistematik Botanik Dergisi 19(1): 1-34. 